\title{
Performance Analysis of Wireless Power Transfer System for Office Communications
}

\author{
Lala Bhaskar ${ }^{1}$, Pradeep Kumar², Kishore Naik Mude ${ }^{3}$ \\ ${ }^{1}$ Amity Institute of Information Technology, Amity University Uttar Pradesh \\ 2 Amity School of Engineering and Technology, Amity University Uttar Pradesh \\ ${ }^{3}$ Systec R\&D, Porto, Portugal
}

(Received 10 January 2021; revised manuscript received 12 June 2021; published online 25 June 2021)

\begin{abstract}
As known, the concept of wireless power transmission is on a hot trail and different organization are working on this concept with different objective but same goal that all want to create system that will run without connection wire for wireless transfer. The interesting part is with the increased distance between the two coils between which magnetic as well as electric field would exist. Our work focuses on exploring the possibilities where in with increased distance between the transmitter and receiver coil we obtain sufficient self-inductance, to charge small appliances. The more the inductance of the receiver coil, more the power output of the coil, sufficient to charge small appliances. This would ensure that optimal voltage and current is obtained for charging the appliances. Results would be obtained by varying the distance between the coil, changing the coil material from copper to other material like aluminum.
\end{abstract}

Keywords: WPT (wireless power transfer), Mobile charger, Laptop charger, Transmitter coil, Receiver coil, Communication system.

DOI: $10.21272 /$ jnep.13(3).03005

PACS number: 84.40.Qx

\section{INTRODUCTION}

In the recent years there is huge interest in public about the concept of wireless power transfer after the acceptance of WIFI globally. The thought of not having the requirement to bring charger or adaptor anywhere would pave way for a new technique of charging devices. Any person can just place the device on the table, and it start charging by itself without any adaptor or cables. The concept of inductivity is widely used for development of such technology and to understand such concept is to first know about its basic theory, Magnetic induction. There are two coil namely primary and secondary coil in which we apply changing current in the primary coil that will in turn produces magnetic field around the primary coil which will change with time thus the changing magnetic field which is created by primary coil can induce a changing current and voltage in secondary coil, and mutual induction (M), of the two coil can be determine by the amount of voltage produce in the secondary coil which is induced by changing current in the primary coil. From this mutual induction which is the phenomenon in which change of current in one coil cause an induced a.m. in another coil placed near to the first coil. Using this theory, we can produce wireless power transfer system and can increase the distance between two inductor or coil, with change in different parameter and can produce enough power in the secondary coil that can charge small appliances. ANSYS HFSS and Maxwell 3D software for simulation of these two coils in accordance to get more accurate result for increasing the distance between the coils and producing wireless power transfer in second coil. Wireless power transfer or WPT is not the new concept. It was demonstrated by the scientist's name "Nikole tesla", As the wireless power transfer main work is to remove wire for power transmission from source to the receiver. It consists of two coils, one of the coil acts as the transmitter and other as a receiver. The transmitter coil is powered by AC current which creates magnetic field around the coil. This magnetic field induces a voltage in the receiver coil. Whenever the receiver coil is located near the magnetic field of the transmitter coil, the magnetic field start to induce an $\mathrm{AC}$ current in the receiving coil.

Mutual induction depends on some factors such as:

1. Size of the primary coil and secondary coil

2. Shape of the primary and secondary coil (i.e., loopy or straight)

3. Number of turns in the coil

4. Distance between the two coils

5. Orientation of the two coils

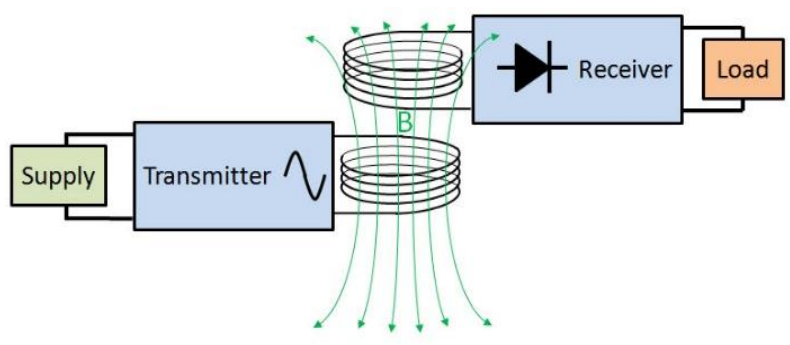

Fig. 1 - Principle of wireless power transfer

Fig. 1 shows wireless power transfer system and has three parts. First, transmitter it supplies power for production of electromagnet wave by the coil. Second, inductive coupling it is the coupling between the transmitter and receiver coils. Third, receiver it receives the power obtained by coupling of two coil and can be rectified for the use of small appliances like mobile for charging etc.

\section{SIMULATION OF WPT}

ANSYS Maxwell 3D software was used to design and simulate the coil system. The software works on the concept of finite element method. It is a simulation 
software for simulating and designing high frequency electronic products such as antennas, microwave components, connectors, IC packages, antenna arrays etc. For simulation of the project the project was divided in parts. The primary coil and secondary coils are designed having windings of 26 turns and 8 turns respectively, with pitch $0 \mathrm{~mm}$ and radius of wire is $3.2 \mathrm{~mm}$. Initially copper material is used for the coils. The coil system is illustrated in Fig. 2.

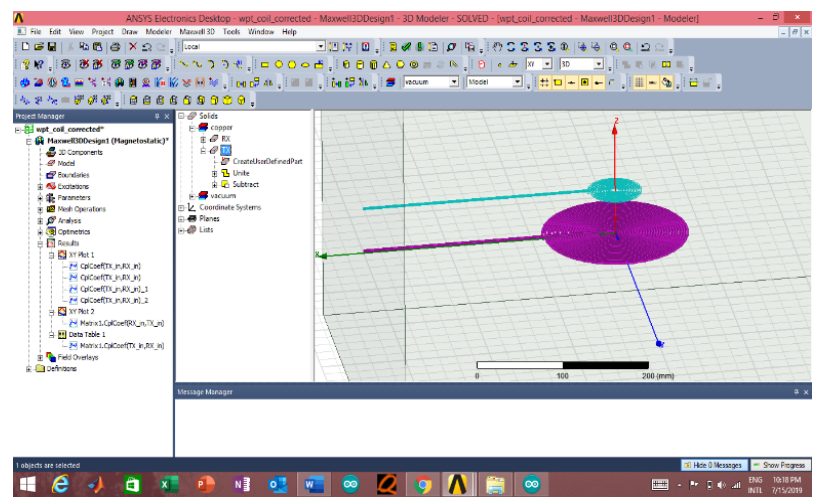

Fig. 2 - Primary coil (Tx) and secondary coil (Rx) in Maxwell $3 \mathrm{D}$ with pink and blue, respectively

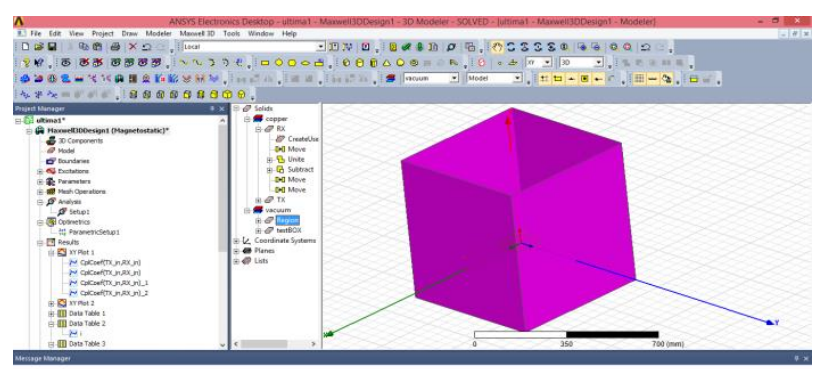

a

Fig. 3 - Primary and secondary coil inside the vacuum box

A vacuum box around the two coils was added. The significance of vacuum box is that it allows us to reduce the wastage of energy and obtain proper linkage of the two coils to ensure smooth simulation process takes place. Excitations were assigned to the ends of both the transmitter $(\mathrm{Tx})$ and receiver $(\mathrm{Rx})$ coil. Excitations are nothing but application of current. Thus, we force the current to drive through the circuit. This ensures, simulation results are obtained as Maxwell 3D requires these parameters to be defined so that simulation can take place.

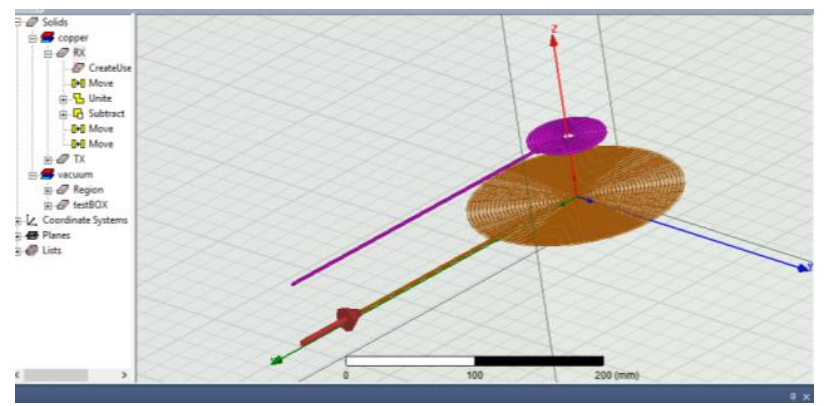

Fig. 4 - Current excitation "Tx" being assigned. The red arrow indicates the direction of current excitation

\section{Simplorer Design Analysis}

After designing the coil system in Maxwell 3D, "Simplorer", another tool part of the Maxwell 3D software was used, for finding out the dependence of the output power and voltage on the frequency of the voltage source applied to the coil system. Therefore, frequency and amplitude of the waveform applied to the coil system would be varied. Thus, a best result would be considered out of many sets of results obtained after simulating the system in Simplorer. To do so, as circuit was designed, which would accommodate the coil system which was designed and simulated in Maxwell 3D.

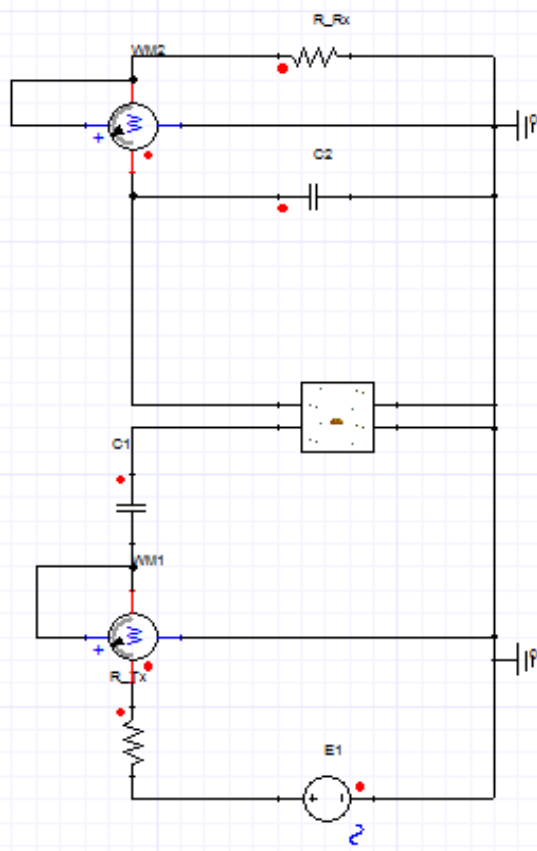

Fig. 5 - Simplorer circuit used for the Simplorer analysis

The capacitor value is taken as 10 micro-Farad, resistance value is taken as $800 \mathrm{Ohms}$. The Watt meters in the circuit are placed such that to measure the voltage or current in that branch. The circuit given above enables Simplorer to find the power output at the receiver coil end as well as the voltage available at the receiver coil. The same would be used to charge or drive any other circuitry.

\section{DISCUSSION OF RESULTS}

The results obtained using Maxwell 3D involve the use of wires made up of two materials copper and aluminum. Current excitations of $1.5 \mathrm{~A}, 5 \mathrm{~A}, 8 \mathrm{~A}$ and $10 \mathrm{~A}$ are applied one at a time and observations are taken. Table 1 shows the mutual inductance values of receiver coil for copper wire with the increase in distance from $20 \mathrm{~mm}$ to $100 \mathrm{~mm}$ between transmitter coil to receiver coil. Fig. 6 shows the plot of mutual inductance of receiver coil with respect to distance. Table 2 shows the mutual inductance values of receiver coil for aluminum wire with the increase in distance from $20 \mathrm{~mm}$ to $100 \mathrm{~mm}$ between transmitter coil to receiver coil. Fig. 7 shows the plot of mutual inductance of receiver coil with respect to distance. 
Table 1 - Mutual induction of receiver coil for copper wire

\begin{tabular}{|c|c|c|c|c|}
\hline $\begin{array}{c}\text { Distance } \\
(\mathrm{mm})\end{array}$ & $\begin{array}{c}\text { Mutual } \\
\text { inductance } \\
(\mu \mathrm{H}) \text { for } \\
1.5 \mathrm{~A}\end{array}$ & $\begin{array}{c}\text { Mutual } \\
\text { inductance } \\
(\mu \mathrm{H}) \text { for } \\
5 \mathrm{~A}\end{array}$ & $\begin{array}{c}\text { Mutual } \\
\text { inductance } \\
(\mu \mathrm{H}) \text { for } \\
8 \mathrm{~A}\end{array}$ & $\begin{array}{c}\text { Mutual } \\
\text { inductance } \\
(\mu \mathrm{H}) \text { for } \\
10 \mathrm{~A}\end{array}$ \\
\hline 20 & 2.0928 & 2.0928 & 2.087 & 2.087 \\
\hline 40 & 1.1094 & 1.1095 & 1.1052 & 1.1052 \\
\hline 50 & 0.827 & 0.8247 & 0.8246 & 0.8246 \\
\hline 60 & 0.6255 & 0.6255 & 0.63 & 0.63 \\
\hline 80 & 0.3759 & 0.3759 & 0.3731 & 0.3731 \\
\hline 100 & 0.2502 & 0.2502 & 0.2368 & 0.2368 \\
\hline
\end{tabular}

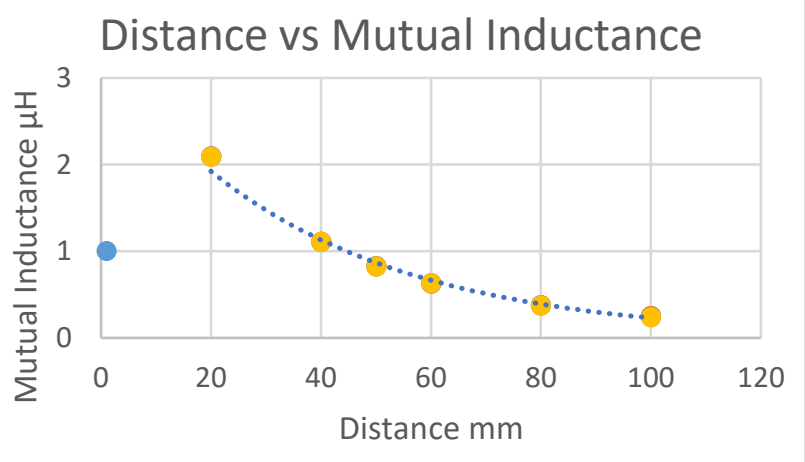

Fig. 6 - Mutual induction of receiver coil vs distance for copper wire

Table 2 - Mutual induction of receiver coil for aluminum wire

\begin{tabular}{|c|c|c|c|c|}
\hline $\begin{array}{c}\text { Distance } \\
(\mathrm{mm})\end{array}$ & $\begin{array}{c}\text { Mutual } \\
\text { inductance } \\
(\mu \mathrm{H}) \text { for } \\
1.5 \mathrm{~A}\end{array}$ & $\begin{array}{c}\text { Mutual } \\
(\mu \mathrm{H}) \text { for } \\
5 \mathrm{~A}\end{array}$ & $\begin{array}{c}\text { Mutual } \\
(\mu \mathrm{H}) \text { for } \\
8 \mathrm{~A}\end{array}$ & $\begin{array}{c}\text { Mutual } \\
(\mu \mathrm{H}) \text { for } \\
10 \mathrm{~A}\end{array}$ \\
\hline 20 & 2.0986 & 3.4314 & 3.4314 & 2.087 \\
\hline 40 & 1.1095 & 1.934 & 1.934 & 1.1052 \\
\hline 50 & 0.8283 & 1.2316 & 1.2316 & 0.8246 \\
\hline 60 & 0.6255 & 0.9478 & 0.9478 & 0.6301 \\
\hline 80 & 0.3781 & 0.5825 & 0.5825 & 0.3731 \\
\hline 100 & 0.2502 & 0.3077 & 0.3077 & 0.2368 \\
\hline
\end{tabular}

\section{CONCLUSIONS}

From the Maxwell 3D analysis, it can be concluded that aluminum wire material is also be a better material for designing coils for wireless power transfer. For instance, while increasing the current excitation from

\section{REFERENCES}

1. M.G.L. Roes, J.L. Duarte, M.A.M. Hendrix, E.A. Lomonova, IEEE Trans. Ind. Electron. 60 No 1, 242 (2013).

2. Y. Hu, X. Zhang, J. Yang, Q. Jiang, IEEE Trans. Ultrason. Ferroelectr. Freq. Control 50 No 7, 773 (2003).

3. A. Sahai, D. Graham, Proc. Int. Conf. Space Opt. Syst. Appl., 164 (Santa Monica: CA: 2011).

4. S. Sasaki, K. Tanaka, Ki. Maki, Proc. IEEE 101 No 6, 1438 (2013).

5. L. Summerer, O. Purcell, Concepts for Wireless Energy Transmission via Laser (2008).

6. J. Dai, D.C. Ludois, IEEE Trans. Power Electron. 30 No 11, 6017 (2015)

7. G.A. Covic, J.T. Boys, Proc. IEEE 101 No 6, 1276 (2013).

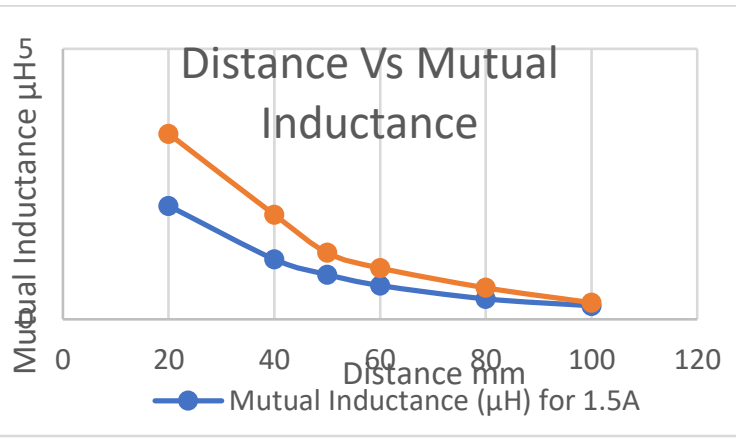

Fig. 7 - Mutual induction of receiver coil vs distance for aluminum wire

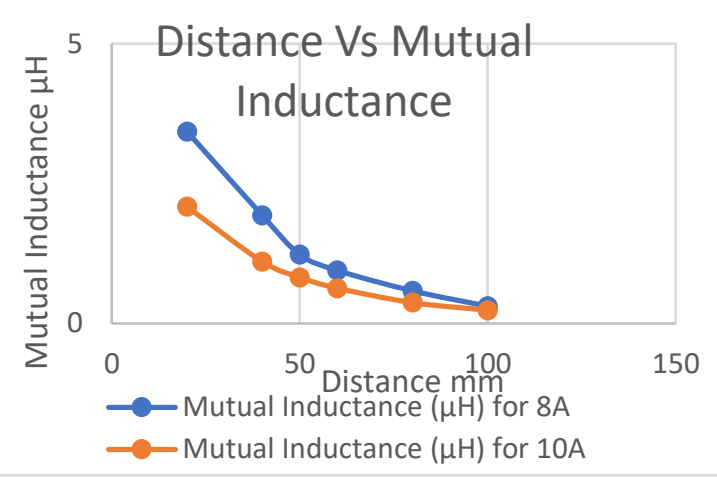

Fig. 8 - Mutual induction of receiver coil vs distance for aluminum wire

1.5 to $5 \mathrm{~A}$ for aluminum wire material, the mutual inductance induced in the receiver coil increases by $61 \%$, while it is negligible change for copper wire material. While increasing the current excitation from $8 \mathrm{~A}$ to $10 \mathrm{~A}$ for aluminum wire material, the mutual inductance induced in the receiver coil starts falling. Therefore, aluminum wire material with current excitation between 1.5 to $5 \mathrm{~A}$, gives the better result and capable to charge small electronic devices, even though the charging speed is slow. Aluminum wire is also suitable for designing wireless power transfer coils. From the Simplorer circuit analysis, amplitude of the input voltage in the range of $20-230 \mathrm{~V}$ AC with a frequency in between $18-20 \mathrm{kHz}$ and a current controlled between 1.5-5 A, using aluminum as wire material for coil designing, yields best results for wireless power transfer systems.
8. N. Tesla, Proc. IEEE 87 No 7, 1282 (1999).

9. S.Y.R. Hui, IEEE Power Electron. Mag. 3 No 1, 14 (2016).

10. H.A. Wheeler, Proc. Inst. Radio Eng. 16 No 10, 1398 (1928).

11. H.A. Wheeler, Proc. IEEE 70 No 12, 1449 (1982).

12. S.S. Mohan, M. del Mar Hershenson, S.P. Boyd, T.H. Lee, IEEE J. Solid-State Circ. 34 No 10, 1419 (1999).

13. Lala Bhaskar, Pradeep Kumar, Kishore Naik Mude, 1st Int. Conf. Adv. Inf. Technol. (ICAIT), 522 (2019).

14. Lala Bhaskar, Pradeep Kumar, Kishore Naik Mude, Int. J. Innovat. Technol. Explor. Eng. (IJITEE) 8 No 9S (2019).

15. Toto Supriyanto, Asri Wulandari, Teguh Firmansyah, Suhendar, Int. J. Inform. Electron. Eng. 6 No 2, 110 (2016). 


\title{
Аналіз продуктивності системи бездротової передачі електроенергії для офісного зв'язку
}

\author{
Lala Bhaskar ${ }^{1}$, Pradeep Kumar², Kishore Naik Mude ${ }^{3}$
}

${ }^{1}$ Amity Institute of Information Technology, Amity University Uttar Pradesh, India

2 Amity School of Engineering and Technology, Amity University Uttar Pradesh, India 3 Systec R\&D, Porto, Portugal

\begin{abstract}
Як відомо, концепція бездротової передачі електроенергії є дуже привабливою, і різні організації працюють над цією концепцією з одніею і тією ж метою: усі хочуть створити систему, яка працюватиме без з'єднувальних дротів для бездротової передачі. Цікавим моментом є збільшена відстань між двома котушками, між якими могло б існувати як магнітне, так і електричне поля. Робота зосереджена на вивченні можливостей, при яких зі збільшенням відстані між котушкою передавача і котушкою приймача ми отримуемо достатню самоіндукцію для зарядки невеликих приладів. Чим більша індуктивність котушки приймача, тим більша вихідна потужність котушки, якої достатньо для зарядки дрібних приладів. Це забезпечило б отримання оптимальної напруги та струму для заряджання приладів. Результати можна отримати, змінюючи відстань між котушками, а також матеріал котушки з міді на інший, такий як алюміній.
\end{abstract}

Ключові слова: Бездротова передача електроенергії, Мобільний зарядний пристрій, Зарядний пристрій для ноутбука, Котушка передавача, Котушка приймача, Система зв'язку. 